Лiтература

1. Лонгмор М. Оксфордский справочник по клинической медицине/М. Лонгмор, Я. Уилкинсон, С. Раджагопалан [пер. с англ.]. -М. : БИНОМ. Лаборатория знаний, 2009. - 855 с.

2. W. James. Psychology: Briefer Course. - N.Y. : H.Holt \& Co, 1893; Вильям Джемс. ПСИХОЛОГИЯ. - М. : Педагогика, 1991. - Режим доступа : http://psylib.org.ua/books/ index.htm.
3. Беспалько В. П. Слагаемые педагогической технологии / В. П. Беспалько. - М. : Педагогика, 1989. - 192 с.

4. Смирнов С. Д. Педагогика и психология высшего образования : от деятельности к личности : учеб. пособие для студ. высш. пед. учеб. заведений / С. Д. Смирнов. -М. : Издат. центр “Академия”, 2001. - 304 с.

УДК 001.5+316.658.2+067.875

\title{
МІЖДИСЦИПЛІНАРНИЙ ПРОБЛЕМНИЙ СЕМІНАР ЯК ІНТЕРАКТИВНИЙ МЕТОД НАВЧАННЯ СЛУХАЧІВ ЦИКЛУ ТЕМАТИЧНОГО УДОСКОНАЛЕННЯ
}

\author{
Б. М. Дикий, Г. Б. Матейко, О. Я. Пришляк, О. Є. Кондрин \\ Івано-Франківський начіональний медичний університет
}

\section{INTERDISCIPLINARY PROBLEMATIC SEMINAR AS AN INTERACTIVE METHOD OF TEACHING STUDENTS OF THE THEMATIC CYCLE OF IMPROVEMENT}

\author{
B. M. Dykyi, H. B. Mateyko, O. Ya. Pryshliak, O. Ye. Kondryn \\ Ivano-Frankivsk National Medical University
}

\begin{abstract}
Використання міждисциплінарного проблемного семінару у вигляді наукової конференції як інтерактивного методу навчання дозволяє виробити і закріпити у лікарів навики застосовування набутих знань у практичній медицині, розвиває професійно-творче мислення, ініціативність, відповідальність, самостійність, дає можливість поділитися власним досвідом з іншими. Семінар розроблений для слухачів циклу тематичного удосконалення (ТУ), оскільки для успішного його проведення необхідний достатній рівень засвосння учасниками семінару провідних ідей, основних понять і положень 3 різних дисциплін, що вивчалися на етапі додипломного навчання. Завдання міждисциплінарного семінару - забезпечити усвідомлення лікарями міжпредметних зв’язків, систематизувати набуті знання, навики і вміння.
\end{abstract}

The author offers a complex use of traditional and problematic forms of education: an interdisciplinary seminar on a scientific conference to address specific clinical situations using "case" method. These learning organic mutually complement each other and compensate for their defects. Interdisciplinary seminar designed for students of 6-th year medical faculty, because for success it requires a sufficient level of learning students leading ideas, concepts, terms from different disciplines that had been studied previously. Interdisciplinary seminar is the most difficult type of seminar; the main task is to ensure students' awareness of intersubject relations, to systematize the knowledge, skills and abilities, to sum up the work. As an interactive teaching method, interdisciplinary seminar allows students to develop skills to apply the best knowledge gained in the unique and unusual situations. Its advantage is that it develops professional and creative thinking, initiative, independence, responsibility, and allows students to share their experience with others.

Вступ. Для підвищення ефективності навчального процесу на етапі післядипломної медичної освіти використовуються сучасні інноваційні технології, зокрема, інтерактивне навчання, а також методи проблемного навчання, які дають можливість лікарям глиб- ше розкрити свої здібності. Структурною одиницею проблемного навчання є проблемна ситуація і процес іiі вирішення. Проблемне навчання не пропонує у готовому вигляді знання і способи діяльності, певні правила і інструкції вирішення завдань. Воно стиму-

( Б. М. Дикий, Г. Б. Матейко, О. Я. Пришляк, О. Є. Кондрин 
лює пошукову, пізнавальну, виконавську діяльність курсантів, розвиток інтересу до предмета, формування самостійності і творчого ставлення до спеціальності. Заняття перетворюється на діалог, спільні роздуми, викладач не декларує, а постійно міркує, полемізує, залучає курсантів до активного пошуку доказів, заснованих на певних професійних знаннях, асоціаціях, практичному досвіді. Проблемне навчання розвиває пізнавальну самостійність, творчий підхід до справи, вчить лікаря думати, мислити, поєднує процес навчання і виховання, засвоєння знань і формування світогляду [2, 5, 7].

Основна частина. Проблемне навчання потребує тривалого часу для вивчення навчального матеріалу, недостатньо ефективне щодо формування практичних умінь і навиків, дає невисокий результат при засвоєнні нового матеріалу, коли самостійний пошук студентам недоступний [6]. Тому, на нашу думку, інтерактивні методи слід застосовувати наприкінці вивчення дисципліни, ще краще, на заняттях з лікарями-інтернами чи курсантами. Це дозволить їм, маючи достатній “багаж” знань, розвивати професійно-творче мислення.

Серед численних форм проблемного навчання ми вибрали міждисциплінарний семінар у вигляді наукової конференції, яка починається із створення найважливішої проблемної ситуаційної задачі чи клінічної ситуації, а завершується ії вирішенням. Семінар складається $з$ двох взаємопов' язаних етапів- самостійного вивчення курсантами матеріалу та обговорення результатів їх самостійної пізнавальної діяльності [1, 4]. Готуючись до семінару, курсанти самостійно вивчають за завданнями викладача окремі питання i теми лекційного курсу з наступним оформленням навчального матеріалу у вигляді рефератів, доповідей, повідомлень. Працюючи на семінарі, лікар вчиться обгрунтовувати і формулювати свої думки, набуває навиків публічних виступів, ведення дискусії, виявляє свої знання, наукову позицію, вчиться їі відстоювати. Виступаючи на семінарі, лікар повинен чітко і лаконічно висловлювати свої думки, не відхилятись від обговорюваної теми, не зачитувати конспект замість усного виступу. Спірні і дискусійні питання, які виникають, вирішуються під керівництвом викладача в процесі докладного обговорення.

Завдання міждисциплінарного семінару - забезпечити усвідомлення лікарями міжпредметних зв'язків, систематизувати їх знання, навики, вміння. Міжпредметні зв'язки дають змогу краще пізнати факти, явища, процеси, сприяють усвідомленню місця тої чи іншої дисципліни в системі медичних наук, їі впливу на підготовку лікаря [1, 3].
Тему семінару обрали одну з актуальних і проблемних - "Інфекційні полінейропатії: патогенез, клініка, діагностика, лікування". На семінарське заняття винесено проблему, яка є предметом вивчення декількох дисциплін (інфектологіі, неврології, педіатрії, реаніматологіi). Будуть обговорюватись складні для розуміння і засвоєння питання в умовах колективної роботи з активною участю кожного курсанта. Технологічна карта розроблена для лікарів-курсантів циклу ТУ “Вибрані питання інфекційних хвороб”.

\section{Навчально-виховні цілі міждисциплінарного семінару \\ Навчальні цілі:}

- систематизувати знання, отримані на кафедрах мікробіології, патологічної фізіології і анатомії, клінічної фармакологіі, інфекційних, нервових, дитячих хвороб, анестезіології і реаніматології у процесі самостійної підготовки лікарів з проблеми інфекційні полінейропатії-проїх етіологію, патогенез, клініку, стани, які загрожують життю, діагностику, лікування;

- шляхом вирішення теоретичних і практичних проблем конкретизувати навики лікарів-курсантів при роботі з хворими з урахуванням особливостей сучасного перебігу бактерійних і вірусних полінейропатій, їх діагностики, ризику розвитку невідкладних станів;

- на основі усвідомлення значення міжпредметних зв'язків для ефективної і успішної роботи лікарівінфекціоністів, педіатрів, невропатологів, реаніматологів поглибити вміння іх надавати адекватну медичну допомогу хворим на інфекційні полінейропатії, здійснювати своєчасні діагностично-лікувальні заходи, надання невідкладної допомоги.

Розвивальні изілі:

- розвинути здатність лікарів-курсантів до логічного мислення у вирішенні проблемних завдань;

- сприяти формуванню вміння самостійно засвоювати знання, аналізувати, синтезувати, абстрагувати, конкретизувати, узагальнювати набуті знання; спонукати лікарів-курсантів до колективного творчого обговорення складних питань, активізувати їх до самостійного вивчення науково-методичної літератури.

\section{виховні цілі:}

- розвинути у лікарів-курсантів професійну ініціативність, самостійність, відповідальність за якість надання медичної допомоги хворим на інфекційні полінейропатії залежно від тяжкості їх перебігу, характеру імунної відповіді хворого, розвитку невідкладних станів;

- підготувати лікарів-курсантів до самостійної роботи з такими хворими. 
Діагностично-корекційна ціль: виявити та ліквідувати можливі прогалини і недоліки у засвоєнні лікарями-курсантами отриманих раніше знань, навиків, вмінь, необхідних при роботі 3 хворими на інфекційніполінейропатії.

Методичний сценарій міждисциплінарного семінару

\section{1. Підzотовчий eman.}

У процесі підготовки до семінару викладач повідомляє лікарям-курсантам тему, план семінарського заняття і рекомендовану літературу (див.: Інструктивна карта семінарського заняття). На етапі підготовки до семінару викладач разом з курсантами визначає тематику доповідей, вимоги до них (науковість, актуальність, доступність, час виступу). Лікарі повинні самостійно підготувати доповіді, викласти їх, виступити в ролі експерта 3 підготовленого фрагмента теми.

Інструктивна карта семінарського заняття для лікарів-курсантів циклу тематичного удосконалення "Вибрані питання інфекційних хвороб"

Тема: “Інфекційні полінейропатії : патогенез, клініка, діагностика, лікування"

Актуальність теми. Полінейропатія (ПНП) запальне, демієнілізуюче захворювання нервової системи, яке характеризується множинним ураженням периферійних нервів і корінців 3 вираженим больовим синдромом, вегетативними і руховими порушеннями. Це поліетіологічне захворювання розвивається на тлі або внаслідок перенесених бактерійних чи вірусних інфекцій. Важливе значення в патогенезі має нейро-алергічний фактор. Провокуючі фактори - переохолодження, перегрівання, стрес. Інфекційні ПНП характеризуються тяжкістю перебігу, частою інвалідизацією (до 10 \%), високою летальністю (від 2 до $11 \%)$. При швидко наростаючих паралічах, особливо висхідного типу, блискавичному перебігу із залученням у процес бульбарних нервів захворювання може призвести до зупинки дихання. Тому при появі бульбарного синдрому треба негайно переводити хворого в реанімаційне відділення. Систематизація і поглиблення знань про інфекційні ПНП буде важливою допомогою в практичній роботі інфекціоністам, педіатрам, невропатологам, реаніматологам.

Мета: на основі систематизації знань із різних галузей медичної науки, усвідомлення значення міждисциплінарних зв' язків шляхом вирішення теоретичних і практичних проблем поглибити навики i вміння лікарів-курсантів проводити діагностику і диференційну діагностику інфекційних полінейропатій, надавати адекватну медичну допомогу хворим на інфекційніполінейропатіі.
Теми доповідей для проведення семінару:

1. Етіологія і патогенез ПНП.

2. Класифікація і клінічна картина інфекційних ПНП, особливості їх перебігу у дітей.

3. Особливості клінічного перебігу бактерійних ПНП (при дифтеріі, ботулізмі, правці, кліщовому бореліозі, кишкових інфекціях: шигельозі, єрсиніозі, черевному тифі, кампілобактеріозі).

4. Особливості клінічного перебігу вірусних ПНП (при грипі, ВІЛ-інфекції герпесвірусних, ентеровірусних інфекціях, кліщовому бореліозі).

5. Критерії діагностики гострої і хронічної демієнілізуючої ПНП. Клінічна характеристика синдромів Гійєна-Барре, Міллера-Фішера, параліча Ландрі.

6. Діагностика і диференційна діагностика ПНП, значимість результатів дослідження ліквору і електронейроміографіі.

7. Основні принципи лікування хворих на ПНП. Сучасні підходи до підвищення ефективності лікування (застосування екстракорпоральних методів детоксикації, імуноглобулінів для внутрішньовенного введення).

8. Сучасна патогенетична терапія при ПНП (нейрометаболіти, антиоксиданти, ноотропи тощо). Значення гормонотерапії і нестероїдних протизапальних засобів.

9. Догляд за хворими на ПНП, моніторинг життєвих функцій. Показання для переводу в реанімаційне відділення, невідкладна допомога.

10. Фізіотерапевтичне та санаторно-курортне лікування, масаж, ЛФК при ПНП.

\section{Рекомендована література}

1. Краткий справочник врача-невролога / под ред. проф. А. А. Скоромца. - СПб. : Сотис, 1999. - 192 с.

2. Левин О. С. Полинейропатии. Клиническое руководство / О. С. Левин. - М. : Медицинское информационное агентство, 2005. - 461 с.

3. Неврология / под ред. М. Самуэльса: пер. с англ. - М. : Практика, 1997. - 638 с.

4. Острые нейроинфекции у детей. Руководство для врачей / под ред. А. П. Зинченко. - Л. : Медицина, 1986. -319 с.

5. Скрипченко Н. В. Современные клинико-патогенетические аспекты инфекционных заболеваний периферической нервной системы у детей и принципы терапии : автореф. дисс. ... д-ра мед. наук / Н.В. Скрипченко. - СПб., 1997. - 46 с.

6. Трошин В. М. Неотложные психоневрологические состояния у детей / В. М. Трошин, В. Д. Трошин, О. В. Трошин. - М. : Триада-Х, 1998. - 634 с.

7. Цинзерлинг В. А. Инфекционные поражения нервной системы: вопросы этиологии, патогенеза и 
диагностики. Руководство для врачей / В. А. Цинзерлинг, М. Л. Чухловина. - СПб. : ЭЛБИ-СПб., 2005. $-448 \mathrm{c}$.

\section{2. Основний етап.}

Семінарське заняття відбувається у формі наукової конференції, яку ведеголовуючий- викладач. Він надає слово всім учасникам, підводить підсумки після кожної доповіді, організовує їі обговорення. Кінцева мета конференції - вирішення найважливішої проблемної клінічної ситуації, яка подається на початковому етапі семінару. Оскільки у лікарів незавжди достатньо знань і умінь для іiі вирішення, то основна частина семінару - заслуховування підготовлених доповідей з того чи іншого аспекту проблеми з використанням провідних ідей і знань із різних дисциплін. Доповідачі виступають у ролі експертів з висвітленого питання. Їхні доповіді рецензуються і оцінюються групою рецензентів iз трьох курсантів. Курсанти, які не згідні з деякими положеннями, висвітленими у доповідях експертів, виступають у ролі опонентів. Після заслуховування кожної доповіді пропонується іï обговорення у формі відповідей на запитання, вирішення нетипових ситуаційних задач, підготовлених викладачем з відповідно вужчого аспекту проблеми. Задачі взято з реального практичного досвіду, складено із недостатніми даними, помилками у формулюванні діагнозу, діагностичній і лікувальній тактиці лікарів. Курсантам пропонується знайти помилки, здійснити пошук необхідної інформації. При розв’ язуванні цих завдань курсанти-експерти оцінюють правильність рішень колег. В кінці основного етапу семінару курсанти намагаються вирішити основну проблемну ситуацію і сформулювати головні недоліки в діагностиці інфекційних полінейропатій, верифікації діагнозу, лікуванні, обстеженні, тактиці ведення хворих.

\section{Література}

1. Бандурка О. Основи психології та педагогіки / О. Бандурка. - Харків : Нац. ун-т, 2003. - 336 с.

2. Дичківська I. М. Інноваційні педагогічні технології: навчальний посібник./ І. М. Дичківська-К. : Академвидав, 2004.-351 c.

3. Зимняя И. Педагогическая психология : учебное пособие / И. Зимняя. - М. : Логос, 2000. -384 с.

4. Комар Ю. Основи навчання студента / Ю. Комар. -

\section{3. Заключний етап.}

Оцінювання знань і набутих вмінь лікарів-курсантів викладачем проводиться у п'ятибальній системі. Оцінюються доповіді, участь у їх обговоренні, запитання, вирішення проміжних задач і основної проблемної. Завершується семінар підведенням підсумків і оголошенням оцінок за теоретичну підготовку, практичні навики і вміння. Наприкінці семінарського заняття 3' ясовується, що курсант засвоїв, чого нового навчився. Для цього доцільне використання методики “3, 2, 1”. Кожен з учасників висловлюється і продовжує думку: “три ідеї, які я виніс із семінару”, “дві ідеї, які мене сьогодні вразили”, “одна ідея, яку я використаю завтра".

Висновок. Сучасний семінар набуває нових властивостей, що відповідають вимогам часу. Його особливостями є підвищений рівень проблемності, міждисциплінарності, широке використання задачного матеріалу, проведення у вигляді наукової конференції, що сприяє розвитку критичного, прогностичного мислення фахівців, формуванню їх вмінь здійснювати різні види професійної діяльності, вирішувати нові проблеми сучасної медицини. Міждисциплінарний семінар як інтерактивний метод навчання забезпечує умови для поглиблення і закріплення знань лікарями, дозволяє активізувати їх до самостійного вивчення науково-методичної літератури, формує навики самоосвіти, спонукає до колективного творчого обговорення найбільш складних питань, допомагає виробити у спеціалістів навики застосування набутих знань на практиці.

Доцільно ширше впроваджувати інтерактивне навчання, удосконалювати методи проблемного навчання лікарів для підвищення ефективності навчального процесу на етапі післядипломної медичної освіти.

Донецьк : ДонДУ, 2004. - Кн. 1. 167 с.

5. Мойсесюк Н. Педагогіка : навчальний посібник / Н. Мойсесюк. -К. : ВАТ КДНК, 2001. -608 с.

6. Фіцула М. Педагогіка вищої школи : навчальний посібник / М. Фіцула . -К. : Академвидав, 2006. - 352 с.

7. Шулікін Д. Завдання і перспективи вищої освіти / Д. Шулікін // Освіта України. - 2007. - № 8. - С. 13-19. 